\title{
歩行形態に着目した幼児連れ歩行者の 安心な歩行環境の検討
}

\author{
吉城 秀治 1 ・辰巳 浩 2 堤 香代子 3 ・ 川浪 晃4 \\ 1正会員 福岡大学助教 工学部社会デザイン工学科（テ814-0180 福岡市城南区七隈8-19-1） \\ E-mail: syoshiki@fukuoka-u.ac.jp \\ 2 正会員 福岡大学教授 工学部社会デザイン工学科（†814-0180 福岡市城南区七隈8-19-1） \\ E-mail: tatsumi@fukuoka-u.ac.jp \\ 3 正会員 福岡大学助教 工学部社会デザイン工学科（テ814-0180 福岡市城南区七隈8-19-1） \\ E-mail: kayoko@fukuoka-u.ac.jp \\ 4福岡市役所（二810-8620 福岡市中央区天神1-8-1） \\ E-mail: kawanami.a01@city.fukuoka.lg.jp
}

\begin{abstract}
少子化対策の一つとして, 子連れであっても安全に安心して外出できる都市環境, 交通環境を整備して いく必要があるものと考えられる。 しかしながら, 最も基本的な移動手段である徒歩についてはこれまで にあまり着目されておらず，歩行環境を具体的にどう整備していくかについては検討が進んでいない.

そこで本研究では, 保護者が子じもを自立的・自発的に歩かせても安心できるような歩行環境の創出が 重要であるとの問題意識のもと, 幼児を持つ保護者を対象にアンケート調査を実施しそのような歩行環境 について検討した. 特に子連れの歩き方, 子の歩かせ方に着目し, 保護者による子どもの歩行制限の実態 の把握と, 子どもを安心して歩かせられるための歩行環境の要因について検討した.
\end{abstract}

Key Words : child raising, traffic safety, pedestrian with infant, walkability

\section{1. はじめに}

人口減少社会に突入した我が国では少子化対策が喫緊 の課題となっており，ハード面からソフト面まで様々な 施策が推進されつつある. 土木計画分野においても，子 育て中の親の社会参加を支援していくために, 子連れで あっても安全に安心して外出できる都市環境, 交通環境 を整備していく必要があるものと考えられる，そこで近 年では，いわゆる「子育てバリアフリー」への対応とし て，平成22年に国土交通省により「安心して子育てがで きる環境整備のあり方に関寸る調查研究1」が害施され ており，子連れの外出環境の現状やニーズ，課題等が整 理されており，妊婦や乳幼児を連れた人が快適に利用で きるような公共施設等のあり方が検討されている.

その一方で子連れでの外出を考える上では，こういっ た扴点の利便性を高めることのみならず，その施設に安 全に安心してアクセスできることも重要である，そこで， 平成25年には「公共交通機関等におけるべビーカー利用 に関する協議会2」」が設置され，電車等における移動環
境の改善に向けた提言がなされており,さらなる取り組 みが進められつつある. しかし, 最も基本的な移動手段 である徒歩についてはこれまでにあまり着目されておら ず，少子化社会において具体的に歩行環境をどう整備し ていくかといったそのあり方については検討が進んでい ない.

ところで歩行環境の整備においては，「安全・安心」 が一つの重要な整備理念となり, 全国各地においてそれ を実現するための取り組みが展開されている．ここで改 めて「安全」および「安心」について整理すると，一般 的に安全とは交通事故件数等の客観的なデー夕に基づく ものであり, 安心とは人々の主観的な評価に基づくもの であるといえる，そしてこれらは，岡村・橋本引による 指摘にもあるように, 必ずしも一致するものではないこ とに留意寸る必要がある. 例えば，近年の交通事故件数 は減少傾向にあり安全な移動環境については整備されつ つあるものの，保護者の交通事故に対する不安意識は依 然として高い状況にある4).このことを踏まえると，歩 行環境のあり方としては安全であることは勿論のこと， 
安心感についても考慮した環境設計が必要であろう.

勿論，これまでにも安心な歩行環境の設計に資するた めの研究は行われてはいるが，子どもを連れている際の 歩行は一般的な歩行とその性質を異にすることから，特 に子連れを対象とした研究が必要になる。しかしながら, 近年では子連れを対象とした研究が行われつつあり外出 行動に着目した研究5), の行われているものの, 子連れ の歩行環境に対する意識については十分には明らかにさ れていない. 子連れの視点に基づいた歩行環境整備を進 めていくための知見は至って不十分な状況にある.

ここで一般的に好奇心が旺盛である幼児期の子どもの 健やかな成長を鑑みると, 保護者が子どもを自立的・自 発的に歩かせても安心できるような歩行環境を創出して いくことが重要であろう.しかしながら，先述のとおり 保護者の交通事故に対する不安意識は高く，保護者と一 緒に移動している際, さらには人優先の場である筈の住 区内の街路を歩行している際であっても子どもを自由に 歩かせることを制限せざるを得ない状況にあるものと考 えられる.

そこで本研究では，保護者による歩行制限の実態を理 解する指標として, 特に子連れの歩き方（子どもの歩か せ方）に着目した．子連れの歩き方は，交通事故等への 不安が高い保護者ほど普段から幼児と手をつなぐなどし て歩行を制限しているなど，子どもの自立的・自発的な 歩行に密接に関わってくるものと考えられる. そして, 子どもを安心して歩かせられる歩行環境を検討していく ために，まず保護者による子どもの歩行制限の実態を把 握する. 普段から子どもを自立して歩行させているグル 一プとそうでないグループに類型化し，それぞれの特徵 を明らかにする. そして，どのような保護者であっても 住区内の街路を安心して歩かせられる具体的な歩行環境 のあり方を検討するために，それぞれのグループが安心 もしくは不安に感じる歩行環境の要因を明らかにするこ とを本研究の目的とする.

\section{2. 調査概要}

アンケート調査は，平成26年9月下旬から11月上旬に 福岡市内の5区(中央区，早良区，城南区，東区，西区) の幼稚園9園と保育園2園に幼児を通わせている保護者を 対象に実施した.アンケートの概要および調査内容を表 -1に示す. 配布・回収方法は幼稚園・保育園の職員によ る幼児の保護者への配布および回収とし，後日，園を訪 問してアンケートを回収するという形で行った。配布部 数は1,760部で回収部数は938部, 回収率 $53.3 \%$ である.

なお，本調査に回答してもらった保護者の属性は，図 -1に示すとおりであり, 女性が98.6\%とほぼ女性の回答
表-1 調查概要

\begin{tabular}{|c|c|}
\hline 配布·回収期間 & 平成26年9月下旬 11月上旬 \\
\hline 配布·回収方法 & $\begin{array}{l}\text { 幼稚園·保育園の職員による幼児の保護者への配 } \\
\text { 布及び回収、後日、袁を訪問しアンケートを回収 }\end{array}$ \\
\hline 配布場所 & $\begin{array}{l}\text { 福岡市内の5区(中央区,早良区,城南区,東区,西区) } \\
\text { の幼稚園9園と保育園2園 }\end{array}$ \\
\hline 配布部数 & 1,760部 \\
\hline 回収部数 & 938部（回収率53.3\%） \\
\hline 調査項目 & \begin{tabular}{|l}
$\mid$ 個人属性、通園幼児数 \\
幼児との歩行実態·歩行形態·交通事故経験 \\
手つなぎ歩行実態 \\
モンタージュ写真での安心な道路の感じ取り方
\end{tabular} \\
\hline
\end{tabular}

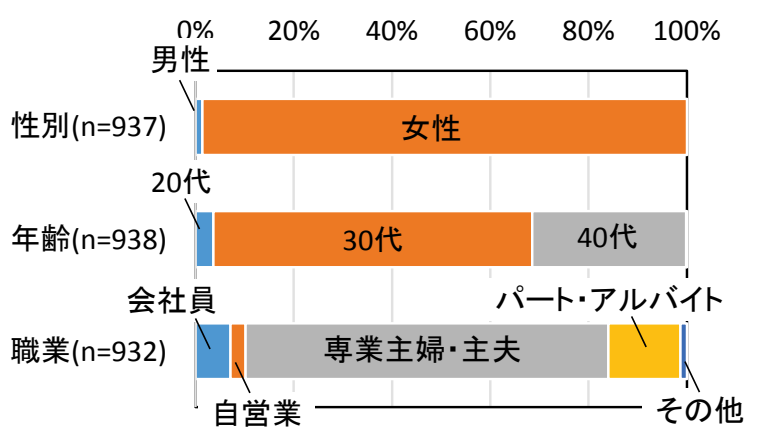

図-1 回答者の属性

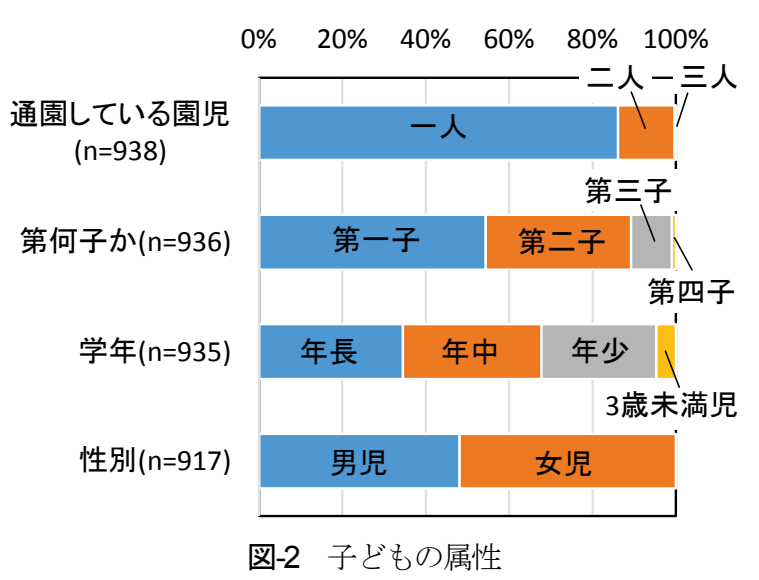

となっている，年齢については30代が最も多く，次いで 40代，20代であった。.また，子どもの属性については図 -2に示すとおりであり，3歳未満児の回答がやや少ない ものの，各学年からサンプリングができていることがわ かる. 一方で, 性別については同程度の割合となってい る.

\section{3. 歩行形態からみる歩行制限の実態とその特徵}

本章では，子どもの自立的・自発的な歩行に対しての 保護者による歩行制限の程度およびその実態を明らかに する. 具体的には，普段の子どもの歩かせ方に基づいて クラスター分析による回答者の類型化後, 各グループの 特徵を明らかにする. 


\section{（1）歩行形態による個人の類型化}

まず本節では道路上における幼児の歩かせ方から歩行 制限の程度に基づく個人の類型化を試みる。ここで一般 的には保護者が子どもの歩行を制限する際には「子と手 をつなぐこと」が多いものと考えられる，そこでまず手 をつなぐこと，あるいはつながないことに対する意識に ついて整理した，その結果を表-2, 表-3に示す．まず手 をつなぐ理由について尋ねた結果では，ほぼ全員が「車 などから安全を確保するため」と回答しており，次いで

「突然走りださないため」となっている，反対に手をつ ながないで歩く理由について尋悋た結果では，「事故に 遭う心配がないから」の選択率が最も高くなっており， 手をつなぐ，つながないの判断は交通安全に関わる理由 が主であるといえる. その一方で，手をつなぐ理由とし て「スキンシップのため」の選択率も約 $50 \%$ となってお り，手をつながない理由として「手がふさがって手をつ なげないから」の選択率が2番目に高くなっているなど, 手をつなぐこと，あるいはつながないことは必ずしも子 どもの安全を確保するためだけではないことがわかる. そこで本研究では，手つなぎの有無のみならず多様な歩 かせ方の頻度について尋㸚, 回答者を分類することにし た.

手つなぎの有無および子どもを歩行させる場所を考慮 して，7タイプの歩かせ方を対象とした．そして，どの ような歩かせ方をさせるかどうかは道路環境に大きく左 右されるものと考えられるため, 回答者には，まず子連 れでも安心して歩ける道路, 子連れでは不安のある道路 を想定してもらい，その上で各道路での幼児の歩かせ方 別の頻度を尋亦た．その結果を図-3に示す．図より，最 もよくしている歩かせ方は「手をつないで子を建物側に 歩かせる」であり，子連れでも安心して歩ける道路，子

表-2 子と手をつないで歩く理由

\begin{tabular}{lr}
\hline \multicolumn{1}{c}{ 手をつなぐ理由 } & 選択率 \\
\hline 車などから安全を確保するため & $98.7 \%$ \\
突然走りださないようにすたた & $54.1 \%$ \\
スキンシップのため & $46.7 \%$ \\
迷子にならないようするすため & $30.4 \%$ \\
転倒しないように守るため & $28.5 \%$ \\
子どもが手をつなぎたがるから & $20.2 \%$ \\
その他 & $0.7 \%$ \\
\hline
\end{tabular}

表-3 手をつながないで歩く理由

\begin{tabular}{lr}
\hline \multicolumn{1}{c}{ 手をつながない理由 } & 選択率 \\
\hline 事故に遭う心配がないから & $45.7 \%$ \\
手がふさがって手をつなげないから & $42.8 \%$ \\
子どもが嫌がるから & $29.7 \%$ \\
できるだけ自立してー人で歩かせたいから & $28.5 \%$ \\
手をつな゙゙と面倒だから & $1.9 \%$ \\
その他 & $6.7 \%$ \\
\hline
\end{tabular}

連れでは不安のある道路の両道路でよく行われている歩 かせ方であることがわかる，反対に，「手をつながない が，横並びで子を車道側で歩かせる」や「手をつないで， 子を車道側で歩かせる」，「抱っこして歩かせない」で は両道路において“しない”の割合が高くなっている. そして，両道路で最も歩かせ方の回答割合に差がみられ たのは「手を放して自由に歩かせる」であった.

この結果から, 安心して歩ける道路, 不安のある道路 でともに “よくする”もしくは“たまにする”と回答し ていた歩かせ方を「どのような道路でもしている(3)」 として，一方の道路では “よくする”もしくは“たまに する”と回答しており，他方の道路では“あまりしな い”もしくは“しない”之回答していた歩かせ方を「状 況次第ではしている(2)」として，ともに“あまりしな い”もしくは“しない”と回答していた歩かせ方を「ど のような道路でもしていない(1)」として回答を整理し た，そして，クラスター分析を適用するために丸括弧内 に記載のとおりの数值をそれぞれに付与し，階層化は Ward法，グループ間の距離は平方ユークリッド距離を 用いて回答者を三つのクラスターに類型化した. クラス ターごとの平均值を表-4に示し, 全体平均よりも高いも のについては赤字で, 低いものについては青字で示して いる.

クラスターごとの平均的に着目寸ると，一つ目のクラ スターは全体平均よりも高い項目が多くなっていること がわかる. 特に, 子を車道側とする歩かせ方の平均值が 他のクラスターと比べると高くなっていることが特徵と してあげられる．二目のクラスターは，一つ目のクラ スターと比べると子を車道側とする歩かせ方の平均值が 低いことに違いがみられる. 三つ目のクラスターについ ては，全体平均よりも低い項目が多くなっていることが わかる. 唯一平均点が高い, つまりどのような道路でも

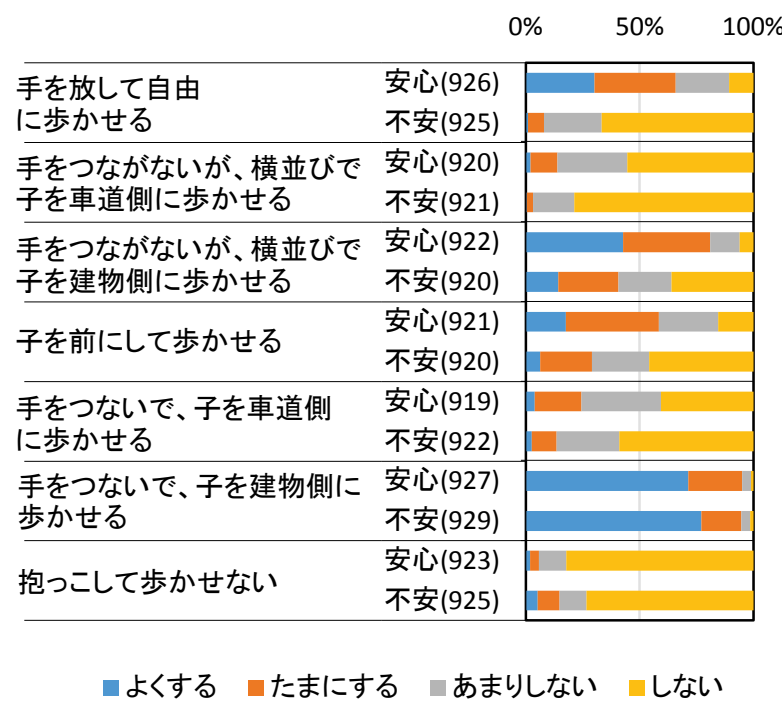

図-3 子どもとの歩行形態 
している歩かせ方は「手をつないで，子を建物側に歩か せる」のみであり，他には「抱っこして歩かせない」の 平均值が他クラスターと比べて高いことも特徵としてあ げられる，以上を踏まえ，一つ目のクラスターを「歩行 制限弱グループ」，二つ目のクラスターを「歩行制限中 グループ」，三つ目のクラスターを「歩行制限強グルー プ」とし，以下それぞれのクラスターの特徴を把握して いく，全体に占める各クラスターの割合としては，歩行 制限弱グループ（196/874），歩行制限強グループ （168/874）がそれぞれ2割程度であり，歩行制限中グル 一プ $(510 / 874)$ が最も多く6割程度となっている。

\section{（2）個人属性や歩行状況からみる各クラスターの特徵}

本節では，各クラスターの特徵を把握するために，個 人属性や日常の歩行状況とのクロス集計を行う。併せて $\chi^{2}$ 検定を行った結果と, 統計的な有意な差がみられた ものについては残差分析の結果も示している.

まず，回答者自身の年齢および子どもの学年との集計 を行った結果を図-4, 図-5に示す. クラスター分類と回

表-4 歩かせ方に基づくクラスター分析結果

\begin{tabular}{|c|c|c|c|c|}
\hline \multirow{2}{*}{ 歩かせ方 } & $\mathrm{C} 1$ & $\mathrm{C} 2$ & C3 & 全体 \\
\hline & $n=196$ & $n=510$ & $n=168$ & $n=874$ \\
\hline 手を放して自由に歩かせる & 2.0 & 1.9 & 1.2 & 1.8 \\
\hline $\begin{array}{l}\text { 手をつながないが、横並び } \\
\text { で子を車道側に歩かせる }\end{array}$ & 1.8 & 1.1 & 1.0 & 1.3 \\
\hline $\begin{array}{l}\text { 手をつながないが、横並び } \\
\text { で子を建物側に歩かせる }\end{array}$ & 2.5 & 2.4 & 1.4 & 2.2 \\
\hline 子を前にして歩かせる & 2.3 & 2.1 & 1.2 & 1.9 \\
\hline $\begin{array}{l}\text { 手をつないで、子を車道側に } \\
\text { 歩かせる }\end{array}$ & 2.3 & 1.3 & 1.4 & 1.5 \\
\hline $\begin{array}{l}\text { 手をつないで、子を建物側に } \\
\text { 歩かせる }\end{array}$ & 2.9 & 2.9 & 2.9 & 2.9 \\
\hline 抱っこして歩かせない & 1.2 & 1.1 & 1.7 & 1.3 \\
\hline
\end{tabular}

·赤字は全体平均よりも高い值、青字は低い值を示す

·数值は、「どのような道路でもしている」を3点、「状況次第ではしている」を 2点、「どのような道路でもしていない」を1点とした場合の平均点
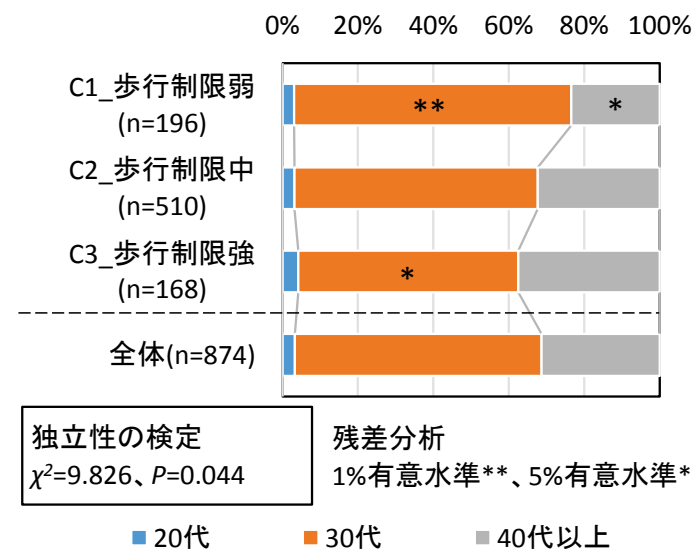

図-4 クラスター別保護者の年齢層
答者自身の年齢層との間には統計的な関係性がみられ， 歩行制限が強いグループであるほど保護者の年齢層が高 くなる傾向にある. 続いて，子どもの学年との関係につ いてみた結果では, 歩行制限が強いグループであるほど

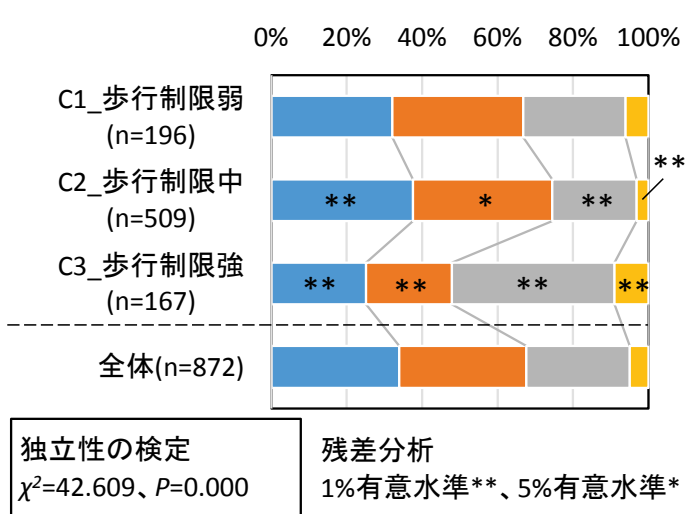

口年長口年中 年少 $、$ 歳未満児

図-5 クラスター別子どもの学年

$\begin{array}{llllll}0 \% & 20 \% & 40 \% & 60 \% & 80 \% & 100 \%\end{array}$

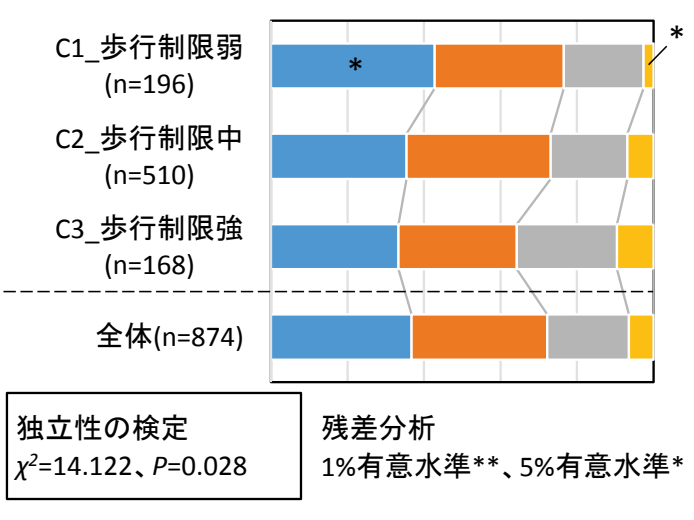

ロ毎日ロ週に3〜6回匹週に数回、月に数回

図-6 クラスター別歩行での外出頻度

$\begin{array}{llllll}0 \% & 20 \% & 40 \% & 60 \% & 80 \% & 100 \%\end{array}$

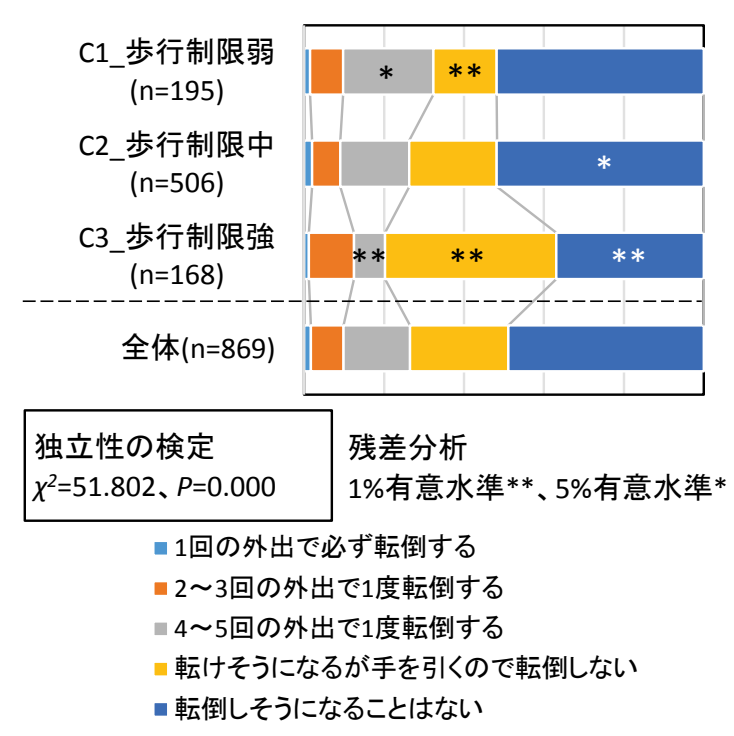

図-7 クラスター別子どもの転倒頻度 
子どもの学年が低いことがわかる. なお，他にも子ども の性別等についても検証しているが統計的な有意差はみ られていない。これら結果より, 比較的年齢が高い保護 者で，また学年が低い子どもを持つ保護者が特に子連れ 歩行時の歩行制限が強い傾向にあるといえる.

続いて, 各クラスターの歩行時の特徵を明確にするこ とを目的として，クラスター別に歩行実態を問うた結果 とのクロス集計を行う．まず，子どもを連れてでの歩行 頻度について尋齐た結果を図-6に示寸，独立性の検定結 果より統計的な有意差がみられ，歩行制限が弱いグルー プのほうが歩行頻度が高くなっている。

次いで転倒経験について尋ねた結果を図-7に示寸，歩 行制限が強いグループほど表-4で示されていたように普 段から手をつないで歩かせることが中心なこともあって 手を引くので転倒しないとの割合が高くなっていること がわかる．一方歩行制限が弱いグループでは普段から手 をつながずに歩かせている場合も多いことから，「転倒 しそうになるが手を引くので転倒しない」との割合が低 くなっているものと考えられる. 歩行制限が弱いグルー プでは子じもは自立した歩行をしており，その結果，転 倒する経験が多くなっているものと考えられる.

\section{4. 保護者の安心感 - 不安感と歩行環境との関係}

前章では，保護者による歩行制限の程度から回答者を 類型化し, その特徵を明らかにしてきた. 続いて本章で は, クラスター別の街路に対する安心感・不安感との関 係を明らかにし，どのような保護者でも子どもを自立 的・自発的に歩かせても安心できるような歩行環境の要 因について検討する.

\section{(1) 手法と集計結果}

安心感あるいは不安感に影響を及ぼす要因を明らかに するため, まず歩道形状の違い, 歩道幅員の広狭, 歩車 分離の有無, 走行車の有無, 沿道の違い, カラー舗装の 有無, 中央線の有無の7つの項目(計14要因)を組み合わせ た8枚のモンタージュ写真を実験計画法のL8直交配列表 に基づき作成した．なお，これらの要因については住区 内の街路に存在し, 空間の再構築を検討寸る際に比較的 容易に変更可能であるものを中心に抽出している．その 組み合わせを表-5に示す. そして，その8枚の写真ごと に「子どもと手を放して自由に歩かせていても安心して 歩けるか」について4段階(安心, やや安心, やや不安, 不安)で尋ねた。その結果を図-8に示寸。図より，ガー ドレールで区分されている道路では安心との回答割合が 高、傾向にある. 一方, 歩道幅員が狭くガードレールが ない「う」では安心して歩けるとの回答がほとんどみら れない. また，クラスター別に集計を行い独立性の検定 を行ったところ, すべての街路において統計的な有意差 がみられた．歩行制限が強いグループほどどのような街 路に対しても不安感が強いことが示されている.

表-5 歩行環境要因の組み合わせ

\begin{tabular}{|c|c|c|c|c|c|c|c|}
\hline 写真 & $\begin{array}{c}\text { (a) } \\
\text { 歩道形状 }\end{array}$ & $\begin{array}{c}\text { (b) } \\
\text { 歩道幅員 }\end{array}$ & $\begin{array}{c}\text { (c) } \\
\text { 歩車分離 }\end{array}$ & $\begin{array}{c}\text { (d) } \\
\text { 走行車 }\end{array}$ & $\begin{array}{c}\text { (e) } \\
\text { 沿道 }\end{array}$ & $\begin{array}{c}\text { (f) } \\
\text { カラー舗装 }\end{array}$ & $\begin{array}{c}\text { (g) } \\
\text { 中央線 }\end{array}$ \\
\hline あ & $\begin{array}{c}\text { a1 マウント } \\
\text { アップ }\end{array}$ & b1 広い & $\mathrm{c} 1$ 有 & $\mathrm{d} 1$ 有 & e1 駐車場 & $\mathrm{f} 1$ 有 & $\mathrm{g} 1$ 有 \\
\hline い & $\begin{array}{c}\text { a1 マウント } \\
\text { アップ }\end{array}$ & b1 広い & c1 有 & d2 無 & e2 戸建て & f2 無 & g2 無 \\
\hline う & $\begin{array}{c}\text { a1 マウント } \\
\text { アップ }\end{array}$ & b2 狭い & c2 無 & d1 有 & e1 駐車場 & f2 無 & g2 無 \\
\hline え & $\begin{array}{c}\text { a1 マウント } \\
\text { アップ }\end{array}$ & b2 狭い & c2 無 & d2 無 & e2 戸建て & f1 有 & $\mathrm{g} 1$ 有 \\
\hline お & a2 フラット & b1 広い & c2 無 & $\mathrm{d} 1$ 有 & e2 戸建て & f1 有 & g2 無 \\
\hline か & a2 フラット & b1 広い & c2 無 & d2 無 & e1 駐車場 & f2 無 & $\mathrm{g} 1$ 有 \\
\hline き & a2 フラット & b2 狭い & c1 有 & $\mathrm{d} 1$ 有 & e2 戸建て & f2 無 & $\mathrm{g} 1$ 有 \\
\hline$<$ & a2 フラット & b2 狭い & c1 有 & d2 無 & e1 駐車場 & f1 有 & g2 無 \\
\hline
\end{tabular}

$0 \% \quad 50 \% \quad 100 \%$

$0 \% \quad 50 \% \quad 100 \%$
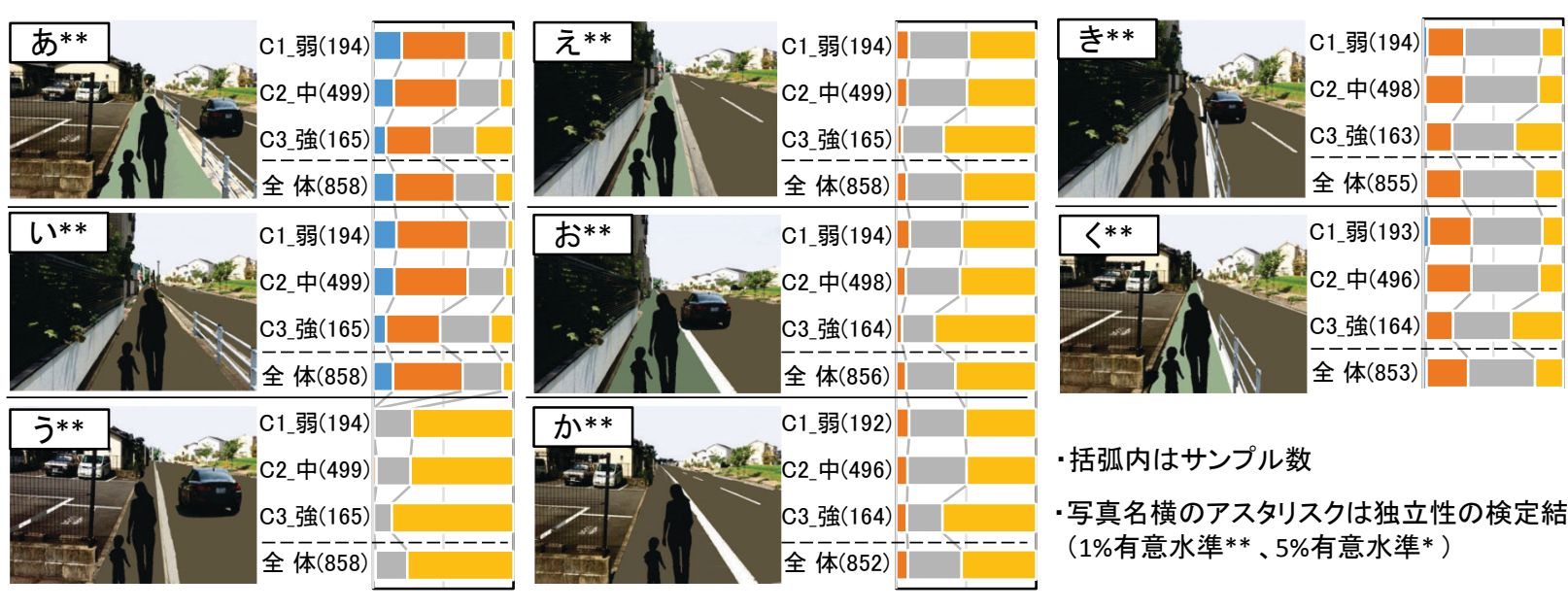

·括弧内はサンプル数

・写真名横のアスタリスクは独立性の検定結果 (1\%有意水準**、5\%有意水準*)

ロ安心して歩ける』やや安心して歩けるロやや不安を感じて歩く』不安を感じて歩く 


\section{(2) 二項ロジスティクス回帰による評価}

そして，この安心感と歩行環境の関係を明らかにする ために，歩行環境評価と歩行環境の要因の関係を多変量 解析により明らかにする。 ここで図-8で示されているよ うに，どの街路であっても“安心して歩ける”との回答 割合が低い，そこで，以降の分析に際してはカテゴリの 統合を行っており，“安心して歩ける”と“やや安心し て歩ける”を「安心」，“やや不安を感じて歩く”“不 安を感じて歩く”を「不安」としている，そして，歩行 環境の要因を説明変数とし，街路に対して安心であると 判断する確率を求める二項ロジスティクス回帰分析をク ラスター別に行った. ステップワイズ法により変数選択 を行い，パラメータを推定した結果を表-6に示す。まず 全体の結果に着目すると, 最も安心感に影響を及ぼすの は歩車分離の有無であり, オッズ比も高い. 次いで歩道 幅員の広さも安心感を高める上での重要な要因であり, 反対に走行車が有ること，沿道が駐車場であることは安 心感を低める要因であることが示されている．続いてク ラスター別の結果に着目すると，歩行制限が強いグルー プについては有意な変数として採用された変数はこれら と走行車のみであり，安心感を高めるために取り得る手 法は少ない，一方，歩行制限が弱いグループや中程度の グループについては歩道形状やカラー舗装についても統 計的に有意な変数として採用されており，これらによっ て安心感を高めることも可能であるといえる.

\section{(3) ラフ集合理論による評価}

前節においては二項ロジスティクス回帰分析により各 要因の影響を定量的に明らかにしてきたが，安心感や不 安感といった街路に対する評価は, 街路空間の要因の組 み合わせによって醸成されていることが想定される．例 えば，自動車が走行していても歩道がマウントアップで あり幅員が広ければ安心であったり，カラー舗装がされ ており歩道が広くてもガードレールがなければ不安に感
じたりと，その判断には街路空間の要因の組み合わせが 大いに関わってくるものと考えられる，そこで本節では 歩道環境整備に向けた具体的な知見を得るためにラフ集 合理論に着目する.

ラフ集合理論》とは，1982年にZ.Pawlakにより提唱され た手法であり，対象の集合をうまく特定できる範囲で情 報を粗く（ラフに）することで，対象の集合のほどよい 記述を求める手法である. 医学や工学, マーケティング, 社会学など多くの応用分野で注目されており, 建築分野 をはじめ土木分野においても適用されている8，9)（手法 の詳細については参考文献わおよびこれらの研究等を参 照されたい)。

まず例として，回答者Aの8種類の街路空間に対する 評価結果が表-7であった場合にラフ集合理論を適用する ことで得られる縮約とC.I.值を表-8示す。ここで縮約と は，対象を識別できるために必要な最小の属性の部分集 合である．また，C.I.值（Covering Index）とは同一の評価 が得られる事例の総数に対する得られた縮約が含まれる 事例数の比である. なお，縮約はC.I.值が高いほど信頼 性が高い，例えば，表-7より「あ」と「い」の2種類の 街路空間に対して安心と判断しており, 残りの6種類の 街路空間に対して不安と判断していることが示されてい る. そして, 表-8の(a)に示すalb1は, 歩道形状がマウン トアップで，歩道幅員が広い場合に回答者Aは安心であ ると判断したことを示す，その右に示すC.I.值は，回答 者Aにより安心であると判断された街路空間のうち, alb1を含みかつ回答者Aにより安心と判断された街路空 間の割合を示す（安心であると判断した2街路中2街路と もalb1を含むため，C.I.值=2/2となる），同様に，表-8の (b)にて示す 22 は, 回答者Aにより不安であると判断され た街路空間のうち，a2を含久かつ不安であると判断され た街路空間の割合となる（不安であると判断した6街路 中4街路にa2を含むため，C.I.值=4/6となる）.

続いて，この各回答者から得られる縮約とC.I.值をク

表-6 クラスター別二項ロジスティクス回帰分析結果

目的変数: 安心である $=1$ 、不安である $=0$

\begin{tabular}{|c|c|c|c|c|c|c|c|c|c|}
\hline \multirow{2}{*}{ 説明変数 } & \multicolumn{2}{|c|}{ C1_歩行制限弱 } & \multicolumn{2}{|c|}{ C2_歩行制限中 } & \multicolumn{2}{|c|}{ C3_歩行制限強 } & \multicolumn{3}{|c|}{ 全体 } \\
\hline & 偏回帰係数 & オッズ比 & 偏回帰係数 & オッズ比 & 偏回帰係数 & オッズ比 & 偏回帰係 & 系数 & オッズ比 \\
\hline 歩道形状(マウントアップ) & $0.367 *$ & 1.443 & $0.493 * *$ & 1.637 & & & $0.319 *$ & ** & 1.376 \\
\hline 歩道幅員 (広) & $1.155 * *$ & 3.173 & $0.933 * *$ & 2.541 & $1.168 * *$ & 3.203 & $1.074 *$ & $* *$ & 2.926 \\
\hline 歩車分離 (有) & $2.678 * *$ & 14.551 & $2.694 * *$ & 14.798 & $2.607 * *$ & 13.468 & $2.730 *$ & $* *$ & 15.331 \\
\hline 走行車 (有) & $-0.317 *$ & 0.729 & $-0.374 * *$ & 0.688 & $-0.272 \dagger$ & 0.762 & $-0.539 *$ & $* *$ & 0.584 \\
\hline 沿道 (駐車場) & $-0.314 \dagger$ & 0.730 & $-0.257 *$ & 0.773 & & & $-0.348 *$ & ** & 0.706 \\
\hline カラー舗装 (有) & $0.398 *$ & 1.488 & $0.213 *$ & 1.238 & & & $0.324 *$ & $* *$ & 1.383 \\
\hline 中央線 (有) & & & & & & & $0.304 *$ & $* *$ & 1.356 \\
\hline 定数項 & $-3.293 * *$ & 0.037 & $-3.199 * *$ & 0.041 & $-3.712 * *$ & 0.024 & $-3.386 *$ & $* *$ & 0.034 \\
\hline 決定係数 & \multicolumn{2}{|c|}{0.2706} & \multicolumn{2}{|c|}{0.2684} & \multicolumn{2}{|c|}{0.2203} & \multicolumn{3}{|c|}{0.2600} \\
\hline モデル適合度 & \multicolumn{2}{|c|}{$P=0.000$} & \multicolumn{2}{|c|}{$P=0.000$} & \multicolumn{2}{|c|}{$P=0.000$} & \multicolumn{3}{|c|}{$P=0.000$} \\
\hline $\mathrm{N}$ & \multicolumn{2}{|c|}{1496} & \multicolumn{2}{|c|}{3760} & \multicolumn{2}{|c|}{1120} & \multicolumn{3}{|c|}{6376} \\
\hline
\end{tabular}

注) $* *: p<0.01 、 *: p<0.05 、 \dagger: p<0.10$ 
ラスター別に集計し，多人数間での評価を求めるために 回答者全員の縮約とC.I.值を算出した．なお，多人数間

表-7 回答者 $\mathrm{A}$ の歩行環境に対する評価

\begin{tabular}{|c|c|c|c|c|c|c|c|c|}
\hline 写真 & $\begin{array}{c}\text { (a) } \\
\text { 歩道形状 }\end{array}$ & $\begin{array}{c}\text { (b) } \\
\text { 歩道幅員 }\end{array}$ & $\begin{array}{c}\text { (c) } \\
\text { 歩車分離 }\end{array}$ & $\begin{array}{c}\text { (d) } \\
\text { 走行車 }\end{array}$ & $\begin{array}{c}\text { (e) } \\
\text { 沿道 }\end{array}$ & $\begin{array}{c}(f) \\
\text { カラー舗装 }\end{array}$ & $\begin{array}{c}\text { (g) } \\
\text { 中央線 }\end{array}$ & $\begin{array}{c}\text { 回答者Aに } \\
\text { よる評価 }\end{array}$ \\
\hline あ & $\begin{array}{c}\text { a1 マウント } \\
\text { アップ }\end{array}$ & b1 広い & c1 有 & d1 有 & e1 駐車場 & $\mathrm{f} 1$ 有 & $\mathrm{g} 1$ 有 & 安心 \\
\hline い & $\begin{array}{c}\text { a1 マウント } \\
\text { アップ }\end{array}$ & b1 広い & c1 有 & d2 無 & e2 戸建 $~$ & $\mathrm{f} 2$ 無 & g2 無 & 安心 \\
\hline j & $\begin{array}{c}\text { a1 マウント } \\
\text { アップ }\end{array}$ & b2 狭い & c2 無 & d1 有 & e1 駐車場 & f2 無 & g2 無 & 不安 \\
\hline え & $\begin{array}{c}\text { a1 マウント } \\
\text { アップ }\end{array}$ & b2 狭い & c2 無 & d2 無 & 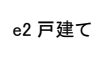 & $\mathrm{f} 1$ 有 & $\mathrm{g} 1$ 有 & 不安 \\
\hline お & a2 フラット & b1 広い & c2 無 & $\mathrm{d} 1$ 有 & e2 戸建て & f1 有 & g2 無 & 不安 \\
\hline か & a2 フラット & b1 広い & c2 無 & d2 無 & e1 駐車場 & $\mathrm{f} 2$ 無 & $\mathrm{g} 1$ 有 & 不安 \\
\hline き & a2 フラット & b2 狭い & c1 有 & $\mathrm{d} 1$ 有 & e2 戸建て & $\mathrm{f} 2$ 無 & $\mathrm{g} 1$ 有 & 不安 \\
\hline$<$ & a2 フラット & b2 狭い & $\mathrm{c} 1$ 有 & d2 無 & e1 駐車場 & f1 有 & g2 無 & 不安 \\
\hline
\end{tabular}

表-8 回答者 $\mathrm{A}$ の縮約結果

(a)回答者Aの「安心」とする縮約

\begin{tabular}{llr}
\hline & \multicolumn{1}{c}{ 縮約 } & C.I. \\
\hline $\mathrm{a} 1 \mathrm{~b} 1$ & 歩道形状(マウントアップ)、歩道幅員(広) & 1 \\
$\mathrm{~b} 1 \mathrm{c} 1$ & 歩道幅員(広)、歩車分離(有) & 1 \\
$\mathrm{a} 1 \mathrm{c} 1$ & 歩道形状(マウントアップ)、歩車分離(有) & 1 \\
$\mathrm{c} 1 \mathrm{~d} 1 \mathrm{e} 1$ & 歩車分離(有)、走行車(有)、沿道(駐車場) & 0.5 \\
$\mathrm{c} 1 \mathrm{~d} 1 \mathrm{f} 1$ & 歩車分離(有)、走行車(有)、カラ一舗装(有) & 0.5 \\
& \multicolumn{1}{c}{} & \\
\hline
\end{tabular}

\begin{tabular}{llr} 
(b)回答者Aの「不安」とする縮約 \\
\hline \multicolumn{2}{c}{ 縮約 } & C.I. \\
\hline a2 & 歩道形状(フラット) & 0.67 \\
b2 & 歩道幅員(狭) & 0.67 \\
c2 & 歩車分離(無) & 0.67 \\
d1f2 & 走行車(有)、カラ一舗装(無) & 0.33 \\
e1f2 & 沿道(駐車場)、カラー舗装(無) & 0.33 \\
& & $\cdots$ \\
\hline
\end{tabular}

での評価を集約する手法として「多人数ルール条件部併 合システム」が提案されている7). しかし，この併合手 法は最大で数十人規模が想定されたものとなっており, 本研究ではそれを大幅に超過していることからその適用 は困難である，そこで本研究では，全回答者（あるいは 各クラスター) に対して, 各縮約がじの程度抽出されて いるのかを算出することで多人数間での評価の集約を試 みた。また，抽出する縮約はC.I.值が高いほど信頼性が 高いことから本研究ではC.I.值が1であった場合のみを対 象とした，安心および不安に関する縮約を整理した結果 を表-9に示す (なお，街路空間要因の組み合わせ数は膨 大でありすべてを記述することは困難なため,ここでは 上位5つまでの縮約を記載している）。

まず，「安心である」とする縮約を整理した結果をみ てみると, alb1，alc1， blc1の選択率が $27.2 \%$ となってお り，これは622名の回答者のうち169名でこれら縮約のC.I. 值が1であったことを示している. そしてクラスター別 の結果に着目すると, クラスターの違いによる縮約とし て選ばれる街路空間要因の組み合わせに違いはみられず, どのクラスターもalb1, alc1, blc1の選択率が同程度に 高くなっていた. このことは，どのグループにとっても 幼児連れで安心して歩行できるためには歩道形状がマウ ントアップであること, 歩道幅員が広いこと, 歩車分離 がされていることが重要であることを示しており，これ らのうち2種類以上が整備されていることでどのクラス ターも安心と感じる人の割合が高まるといえる. 続いて 「不安である」とする縮約についてみてみると, クラス ター間の違いがみられないことは安心に関する縮約結果 と同様であるが，選択率が最も高くなっていたのはc2の

表-9 クラスター別「安心である」とする縮約，および「不安である」とする縮約

\begin{tabular}{|c|c|c|c|c|c|c|}
\hline クラスター & & 「安心である」とする縮約 & 選択率 & & 「不安である」とする縮約 & 選択率 \\
\hline \multirow{5}{*}{$\begin{array}{c}\text { C1_ } \\
\text { 歩行 } \\
\text { 制限弱 } \\
(n=157)\end{array}$} & a1b1 & 歩道形状(マウントアップ)、歩道幅員(広) & $28.7 \%$ & $\mathrm{c} 2$ & 歩車分離(無) & $11.5 \%$ \\
\hline & a1c1 & 歩道形状(マウントアップ)、歩車分離(有) & $28.7 \%$ & $\mathrm{a} 1 \mathrm{c} 2 \mathrm{~d} 1$ & 歩道形状(フラット)、歩車分離(無)、走行車(有) & $1.9 \%$ \\
\hline & $\mathrm{b} 1 \mathrm{c} 1$ & 歩道幅員(広)、歩車分離(有) & $28.7 \%$ & $\mathrm{a} 1 \mathrm{c} 2 \mathrm{e} 1$ & 歩道形状(フラット)、歩車分離(無)、沿道(駐車場) & $1.9 \%$ \\
\hline & $\mathrm{c} 1$ & 歩車分離(有) & $11.5 \%$ & $\mathrm{~b} 2 \mathrm{c} 2 \mathrm{~d} 1$ & 歩道幅員(狭)、歩車分離(無)、走行車(有) & $1.9 \%$ \\
\hline & $\mathrm{a} 1 \mathrm{~b} 1 \mathrm{~d} 2$ & 歩道形状(マウントアップ)、歩道幅員(広)、走行車(無) & $10.8 \%$ & b2c2e1他 & 歩道幅員(狭)、歩車分離(無)、沿道(駐車場) 他 & $1.9 \%$ \\
\hline \multirow{5}{*}{$\begin{array}{c}\text { C2_ } \\
\text { 歩行 } \\
\text { 制限中 } \\
(n=374)\end{array}$} & $\mathrm{a} 1 \mathrm{~b} 1$ & 歩道形状(マウントアップ)、歩道幅員(広) & $25.4 \%$ & $\mathrm{c} 2$ & 歩車分離(無) & $15.5 \%$ \\
\hline & a1c1 & 歩道形状(マウントアップ)、歩車分離(有) & $25.4 \%$ & $\mathrm{a} 1 \mathrm{~b} 2$ & 歩道形状(マウントアップ)、歩道幅員(狭) & $1.3 \%$ \\
\hline & $\mathrm{b} 1 \mathrm{c} 1$ & 歩道幅員(広)、歩車分離(有) & $25.4 \%$ & a1c2 & 歩道形状(マウントアップ)、歩車分離(無) & $1.3 \%$ \\
\hline & $\mathrm{c} 1$ & 歩車分離(有) & $15.5 \%$ & $\mathrm{~b} 2 \mathrm{c} 2$ & 歩道幅員(狭)、歩車分離(無) & $1.3 \%$ \\
\hline & $\mathrm{a} 1 \mathrm{~b} 1 \mathrm{~d} 2$ & 歩道形状(マウントアップ)、歩道幅員(広)、走行車(無) & $11.8 \%$ & c2d1他 & 歩車分離(無)、走行車(有) 他 & $1.1 \%$ \\
\hline \multirow{5}{*}{$\begin{array}{c}\text { C3_ } \\
\text { 歩行 } \\
\text { 制限強 } \\
(n=91)\end{array}$} & $\mathrm{a} 1 \mathrm{~b} 1$ & 歩道形状(マウントアップ)、歩道幅員(広) & $31.9 \%$ & $\mathrm{c} 2$ & 歩車分離(無) & $17.6 \%$ \\
\hline & a1c1 & 歩道形状(マウントアップ)、歩車分離(有) & $31.9 \%$ & a1c2d1 & 歩道形状(フラット)、歩車分離(無)、走行車(有) & $2.2 \%$ \\
\hline & $\mathrm{b} 1 \mathrm{c} 1$ & 歩道幅員(広)、歩車分離(有) & $31.9 \%$ & a1c2e1 & 歩道形状(フラット)、歩車分離(無)、沿道(駐車場) & $2.2 \%$ \\
\hline & $\mathrm{c} 1$ & 歩車分離(有) & $17.6 \%$ & $\mathrm{~b} 2 \mathrm{c} 2 \mathrm{~d} 1$ & 歩道幅員(狭)、歩車分離(無)、走行車(有) & $2.2 \%$ \\
\hline & $\mathrm{a} 1 \mathrm{~b} 1 \mathrm{~d} 2$ & 歩道形状(マウントアップ)、歩道幅員(広)、走行車(無) & $12.1 \%$ & b2c2e1他 & 歩道幅員(狭)、歩車分離(無)、沿道(駐車場) 他 & $2.2 \%$ \\
\hline \multirow{5}{*}{$\begin{array}{c}\text { 全体 } \\
(n=622)\end{array}$} & $\mathrm{a} 1 \mathrm{~b} 1$ & 歩道形状(マウントアップ)、歩道幅員(広) & $27.2 \%$ & $\mathrm{c} 2$ & 歩車分離(無) & $14.8 \%$ \\
\hline & a1c1 & 歩道形状(マウントアップ)、歩車分離(有) & $27.2 \%$ & $\mathrm{a} 1 \mathrm{~b} 2$ & 歩道形状(マウントアップ)、歩道幅員(狭) & $1.1 \%$ \\
\hline & $\mathrm{b} 1 \mathrm{c} 1$ & 歩道幅員(広)、歩車分離(有) & $27.2 \%$ & $\mathrm{a} 1 \mathrm{c} 2$ & 歩道形状(マウントアップ)、歩車分離(無) & $1.1 \%$ \\
\hline & $\mathrm{c} 1$ & 歩車分離(有) & $14.8 \%$ & $\mathrm{~b} 2 \mathrm{c} 2$ & 歩道幅員(狭)、歩車分離(無) & $1.1 \%$ \\
\hline & $\mathrm{a} 1 \mathrm{~b} 1 \mathrm{~d} 2$ & 歩道形状(マウントアップ)、歩道幅員(広)、走行車(無) & $11.6 \%$ & b2c2e1他 & 歩道幅員(狭)、歩車分離(無)、沿道(駐車場) 他 & $1.0 \%$ \\
\hline
\end{tabular}


歩車分離がされていないことであった，これは，安心感 については街路空間の組み合わせによって判断されてい るものの, 不安感については, 歩車分離がされていない ことのみで多くの人が不安と判断していることが示され ている.

\section{5. おわりに}

歩行環境の整備においては安全・安心が一つの重要な 整備理念となる一方, 必ずしも客観的な数值に基づく安 全と主観的な評価に依存する安心は一致しないことがあ る. そのような状況において, 本研究では歩行空間が安 全であることは当然のこととして, 歩行環境における安 心感についても考慮した整備を進めていくための検討を 進めてきたものである. とりわけ少子化・子育て対策が 喫緊の課題となっている現状において, 保護者が子ども を自立的・自発的に歩かせても安心できるような歩行環 境の創出のために，保護者による子どもの歩行制限の実 態の把握と, 子どもを安心して歩かせられるための歩行 環境の要因について検討した.

まず，保護者による子どもの歩かせ方に着目した結果， 「手をつないで子を建物側に歩かせる」ことがよくされ ており，反対に，「手をつながないが，横並びで子を車 道側で歩かせる」や「手をつないで，子を車道側で歩か せる」，「抱っこして歩かせない」はあまりされていな い結果となった。 さらに，これらの回答を基にクラスタ 一分析により回答者を類型化した結果，様々な歩かせ方 をさせている歩行制限が弱いグループ，建物側を手をつ ないで歩かせることが主な歩行制限が強いグループ，そ の間の歩行制限が中程度のグループに分類できている.

そして，これらのグループ別に普段の歩行状況との関係 について分析した結果，歩行制限が弱いグループでは転 倒経験は多い一方で幼児は自立した歩行をしている傾向 にあった。

続いて，子どもを自立的・自発的に歩かせても安心で きるような歩行環境について検討するために, 保護者の 安心感と街路空間要因の関係を分析した. まず, 二項口 ジスティクス回帰分析による結果では, 安心感に最も影 響を及ぼす要因は歩車分離の有無であり, 次いで歩道幅 員の広さも安心感を高める上での重要な要因であった. 反対に走行車が有ること，沿道が駐車場であることは安 心感を低める要因であることが示されている，また，ク ラスター別にパラメータを推計した結果, 歩行制限が強 いグループについては有意な変数として採用された変数 は少なくなっており，これらの人々に対して安心感を高 めるために取り得る手法は少ない. 一方, 歩行制限が弱 いグループや中程度のグループについては歩道形状やカ
ラー舗装についても統計的に有意な変数として採用され ており,これらによって安心感を高めることも可能であ ることが明らかになった。

さらに, 安心感や不安感といった街路に対する評価は, 街路空間の要因の組み合わせによって醸成されることが 想定されることから，ラフ集合理論を用いた分析を行っ た. その結果, どのグループにおいても歩車分離がなさ れていないことのみで不安と判断されてしまうことが明 らかになった. 一方で安心感については, 歩道形状がマ ウントアップであること, 歩道幅員が広いこと, 歩車分 離であることのうちの2種類以上の組み合わせで, 安心 と判断されていることが明らかになっている.

以上本研究は, 保護者による歩行制限の実態を理解す る指標として子連れの歩き方（子どもの歩かせ方）に着 目し，保護者の歩行制限の意思に基づきサンプルを類型 化した上で分析を進めてきた. しかし，子どもの歩かせ 方は，子どもが急に走りだしてしまうから手をつなぐ等 の子どものパーソナリティにも大きく左右されるもので もあるが，本分析ではそれを考慮できていない，今後の 課題として, 歩行環境と歩行制限の関係の更なる理解に 向けては保護者および子どもの両視点に基づく分析が必 要なものと思われる.

\section{参考文献}

1) 国土交通省：安心して子育てができる環境整備のあ り方に関する調查研究, 2010 .

2) 国土交通省 : 公共交通機関等におけるべビーカー利 用に関する協議会, http://www.mlit.go.jp/sogoseisaku/ barrierfree/sosei_barrierfree_mn_000010.html（最終閲覧 2015.4)

3) 岡村篤, 橋本成仁: 生活道路における交通安全と防 犯の「安心・不安」に対寸る意識構造分析一街路空 間の構成要素と個人の地域社会とのつながりに着目 して一, 都市計画論文集, Vol. 50, No. 3, pp. 703-708, 2015.

4) 株式会社イード「母親の子育てや子どもの安全に関 する意識調查」, http://www.iid.co.jp/news/report/2015/ 042301.html，2016.2.26最終閲覧

5) 北川啓介, 長坂真理子, 呉明宣, 井上暁代 : 妊婦と 乳幼児帯同者の行動制限とその要因, 日本建築学会 計画系論文集，Vol. 73, No. 628, pp. 1243-1250, 2008.

6) 大森宣暁, 谷口綾子, 真鍋陸太郎, 寺内義典, 青野 貞康 : 子育て中の女性の外出行動とバリアに対する 意識に関する研究一首都圈在住の乳幼児を持つ母親 を対象として一, 都市計画論文集, Vol. 46, No. 3, pp. 259-264, 2011.

7) 森典彦, 田中英夫, 井上勝雄 : ラフ集合と感性一デ 一夕からの知識獲得と推論一, 海文堂, 2004.

8）宗本晋作：ラフ集合を用いた空間要素の組み合わせ 推論に基づく印象評価の研究一国立民俗学博物館の 企画展を対象として一, 日本建築学会計画系論文集, No. 608, pp. 235-241, 2006.

9) 松井哲平, 佐々木葉 : 新機能主義橋梁デザインの評 


\section{RELATIONSHIPS BETWEEN EVALUATION OF WALKABILITY FOR PEOPLE WITH INFANTS AND STREET STRUCTURES}

\section{Syuji YOSHIKI, Hiroshi TATSUMI, Kayoko TSUTSUMI and Akira KAWANAMI}

In an aging society with fewer children, promoting a safety and security environment for people with infants is growing more important. This study focuses on improving walkability, and the questionnaire survey for people with infants was carried out in Fukuoka city.

Behavior of people with infants and the consciousness on street were examined. The results shows that the relationships between street structures and security mind using binomial logistic regression and rough set analysis. 